\title{
Time Course and Magnitude of Synthesis of Heat-Shock Proteins in Congeneric Marine Snails (Genus Tegula) from Different Tidal Heights
}

\author{
Lars Tomanek ${ }^{*}$ \\ George N. Somero \\ Hopkins Marine Station, Stanford University, Pacific Grove, \\ California 93950-3094
}

Accepted 1/24/00

\begin{abstract}
The time course and magnitude of the heat-shock response in relation to severity of thermal stress are important, yet poorly understood, aspects of thermotolerance. We examined patterns of protein synthesis in congeneric marine snails (genus Tegula) that occur at different heights along the subtidal to intertidal gradient after a thermal exposure $\left(30^{\circ} \mathrm{C}\right.$ for $2.5 \mathrm{~h}$, followed by $50 \mathrm{~h}$ recovery at $13^{\circ} \mathrm{C}$ ) that induced the heat-shock response. We monitored the kinetics and magnitudes of protein synthesis by quantifying incorporation of ${ }^{35} \mathrm{~S}$-labeled methionine and cysteine into newly synthesized proteins and observed synthesis of putative heat-shock proteins (hsp's) of size classes 90, 77, 70 , and $38 \mathrm{kDa}$. In the low- to mid-intertidal species, Tegula funebralis, whose body temperature frequently exceeds $30^{\circ} \mathrm{C}$ during emersion, synthesis of hsp's commenced immediately after heat stress, reached maximal levels $1-3 \mathrm{~h}$ into recovery, and returned to prestress levels by $6 \mathrm{~h}$, except for hsp90 (14 h). In contrast, in the low-intertidal to subtidal species, Tegula brunnea, for which $2.5 \mathrm{~h}$ at $30^{\circ} \mathrm{C}$ represents a near lethal heat stress, synthesis of hsp's commenced 2-14 h after heat stress; reached maximal levels after 15-30 h, which exceeded magnitudes of synthesis in T. funebralis; and returned to prestress levels in the case of hsp90 $(50 \mathrm{~h})$ and hsp77 $(30 \mathrm{~h})$ but not in the case of hsp70 and hsp38. Exposures to $30^{\circ} \mathrm{C}$ under aerial (emersion) and aquatic (immersion) conditions resulted in differences in hsp synthesis in T. brunnea but not in T. funebralis. The different time courses and magnitudes of hsp synthesis in these congeners suggest that the vertical limits of their distributions may be set in part by thermal stress.
\end{abstract}

\footnotetext{
${ }^{\star}$ To whom correspondence should be addressed; e-mail: tomanekl@
} leland.stanford.edu.

Physiological and Biochemical Zoology 73(2):249-256. 2000. (C) 2000 by The University of Chicago. All rights reserved. 1522-2152/2000/7302-99117\$03.00

\section{Introduction}

The heat-shock response, a cellular stress response in which molecular chaperones known as heat-shock proteins (hsp's) are synthesized following thermal stress, occurs in almost all cells (Parsell and Lindquist 1993, 1994; Feige et al. 1996). Hsp's reduce aggregation of thermally unfolded proteins, assist in their refolding, and help to channel irreversibly denatured proteins toward proteolytic degradation. These functions of hsp's are viewed as critical for thermotolerance (Parsell and Lindquist 1993, 1994; Morimoto 1998; Feder and Hofmann 1999). The importance of the heat-shock response under natural conditions is indicated by the observations that synthesis of hsp's is activated near the upper temperatures that ectothermic species encounter in their habitats (Hofmann and Somero 1995; Roberts et al. 1997; Tomanek 1999; Tomanek and Somero 1999), that increased resistance to heat stress is correlated with previous elevations in levels of hsp's (Feder and Hofmann 1999), and that the magnitude of hsp synthesis may be proportional to the severity of heat stress (DiDomenico et al. 1982b; Lindquist 1993). However, several characteristics of the heat-shock response related to heat stress encountered under natural conditions remain to be well characterized. For example, the time course of synthesis of hsp's in relation to the periodicity of environmental heat stress has received little study, despite the fact that the contribution of the heat-shock response to thermotolerance is likely to depend on the rate at which it can be induced under field conditions. Nor has the relationship between the severity of heat stress, which is a complex function of (1) the absolute temperature of stress, (2) the rate at which heating occurs, and (3) the duration of stress, and the synthesis of hsp's been well characterized.

Rocky intertidal habitats, in which large variations in temperature occur during the tidal cycle, contain excellent study species for examining these questions. For example, molluscs of the genera Mytilus (mussels) and Tegula (snails) undergo increases in body temperatures of up to $20^{\circ}-25^{\circ} \mathrm{C}$ during emersion, and this pattern of thermal exposure can reoccur within $24 \mathrm{~h}$ during a series of midday low tides (Hofmann and Somero 1995; Tomanek and Somero 1999). Temperature exposures that are experienced during emersion have been shown to activate 
the heat-shock response in Mytilus congeners (Roberts et al. 1997) and in congeners of Tegula (Tomanek and Somero 1999). Congeners of these two genera that occupy distinct thermal niches differ in the temperatures at which hsp's are induced and the magnitude of hsp synthesis. These differences suggest that critical properties of the heat-shock response are strongly related to adaptation and acclimatization temperatures (Hofmann and Somero 1996a; Tomanek and Somero 1999). Because hsp synthesis caused by thermal stress experienced during emersion commences after reimmersion (Hofmann and Somero 1996b), the time available to repair thermal damage to proteins and to prepare the organism for the next episode of heat stress is limited, and the time course of hsp synthesis is likely to be of importance for species' thermotolerance.

To investigate how the magnitude of the heat-shock response varies in differently adapted congeners and to determine how the temporal patterning of hsp synthesis correlates with tidal period, we followed the time course of hsp synthesis during a $50 \mathrm{~h}$ recovery period subsequent to a $2.5 \mathrm{~h}$ exposure to $30^{\circ} \mathrm{C}$ in the subtidal to low-intertidal snail Tegula brunnea and the low- to mid-intertidal congener Tegula funebralis, species that differ in thermotolerance by $6.5^{\circ} \mathrm{C}$ (Tomanek and Somero 1999). These laboratory exposure conditions were designed to simulate environmental conditions that may occur in the lowto mid-intertidal zone during midday low tides. During emersion, body temperatures of $30^{\circ} \mathrm{C}$ are common for T. funebralis, but not for T. brunnea (Tomanek and Somero 1999). For the latter species, $30^{\circ} \mathrm{C}$ is an extreme (near lethal) temperature. Synthesis of proteins was followed by measuring incorporation of ${ }^{35} \mathrm{~S}$-methionine and ${ }^{35} \mathrm{~S}$-cysteine into newly synthesized proteins in gill tissue. We quantified the relative amount of new synthesis of putative hsp's belonging to four size classes, $90 \mathrm{kDa}$ (hsp90), $77 \mathrm{kDa}$ (hsp77), $70 \mathrm{kDa}$ (hsp70), and $38 \mathrm{kDa}$ (hsp38).

We addressed the following questions: (1) How do the magnitude and timing of the heat-shock response vary with the severity of heat stress in differently thermally adapted congeners? (2) Does the time required to induce and complete the synthesis of hsp's reflect the periodicity of the tidal cycle? (3) Do different size classes of hsp's differ in their expression patterns (intensity and timing) within a species? (4) How do the severity of heat stress and the magnitude and timing of the heat-shock response differ between aerial and aquatic exposures to high temperature? (5) To what extent does the time course of the heat-shock response represent an experimentally important variable to incorporate in studies designed to elucidate the importance of hsp's in field populations?

\section{Material and Methods}

Distribution, Collection Site, and Maintenance of Organisms

Tegula brunnea (Philippi), which inhabits the subtidal to lowintertidal zone, occurs in the eastern Pacific Ocean from Cape
Arago, Oregon $\left(43^{\circ} 25^{\prime} \mathrm{N}\right)$, to the Channel Islands, California $\left(34^{\circ} 00^{\prime} \mathrm{N}\right.$; Abbott and Haderlie 1980; Riedman et al. 1981; Watanabe 1984). Tegula funebralis (Adams), which is restricted to the low- to mid-intertidal zone, occurs over a wider latitudinal range, from Vancouver Island, British Columbia $\left(48^{\circ} 25^{\prime} \mathrm{N}\right)$, to central Baja California $\left(28^{\circ} 00^{\prime} \mathrm{N}\right.$; Abbott and Haderlie 1980; Riedman et al. 1981).

Specimens of both species were collected at the beginning of November 1997 at Hopkins Marine Station of Stanford University in Pacific Grove, California $\left(36^{\circ} 36^{\prime} \mathrm{N}, 121^{\circ} 54^{\prime} \mathrm{W}\right)$, and kept at $13^{\circ} \mathrm{C}$ for a $29-\mathrm{d}$ period prior to experimentation. Specimens were kept constantly immersed and were fed regularly with freshly collected giant kelp (Macrocystis pyrifera).

\section{Survival of Whole Snails after Heat Shock}

Laboratory-acclimated $\left(13^{\circ} \mathrm{C}\right)$ specimens of both species were exposed to $30^{\circ} \mathrm{C}$ for $2.5 \mathrm{~h}$, and survival was assessed afterward at $13^{\circ} \mathrm{C}$ over a 50 -h time period by prodding the underside of the foot. If the foot withdrawal response did not occur, the snail was regarded as dead.

\section{Heat-Shock Protocol and Tissue Preparation: Time Course of Heat-Shock Protein Expression}

The $13^{\circ} \mathrm{C}$-acclimated specimens of T. funebralis and T. brunnea were exposed to aerated seawater (SW) of $13^{\circ} \mathrm{C}$ (control group) and $30^{\circ} \mathrm{C}$ for $2.5 \mathrm{~h}$. This period of exposure is much shorter than the full period of emersion and is also, in general, shorter than the period of heat stress that is frequently encountered at low tide in the mid-intertidal zone (Tomanek and Somero 1999). Thus, the thermal stress we applied was not extreme for T. funebralis but was extreme for the low-intertidal to subtidal T. brunnea, which rarely gets emersed. After exposure to $30^{\circ} \mathrm{C}$, snails were returned to $13^{\circ} \mathrm{C}$ for 0 (control and treatment group), $0.5,1,2,3,4,6,8,10,12,14,29$, and $50 \mathrm{~h}$. At each time point, gill tissue was dissected from five individuals of each species (dissections were completed within a $30-\mathrm{min}$ period) under non-heat-shock temperature conditions $\left(13^{\circ} \mathrm{C}\right)$. Then gill tissue was placed into $13^{\circ} \mathrm{C}$-preequilibrated microcentrifuge tubes containing $0.2 \mu \mathrm{m}$ filtered SW with $10 \mathrm{mM}$ glucose and ${ }^{35} \mathrm{~S}$-methionine and ${ }^{35} \mathrm{~S}$-cysteine (NEN) and incubated for $4 \mathrm{~h}$ under aeration. Higher concentrations of labeled amino acids were used for T. brunnea (12.21 $\mathrm{MBq} \mathrm{mL}^{-1}$; 30.0-45.0 mg wet wt) than for T. funebralis $\left(8.14 \mathrm{MBq} \mathrm{mL}^{-1}\right.$; $15.0-25.0 \mathrm{mg}$ wet wt) to compensate for higher tissue mass and lower uptake rates in the former species. Levels of hsp's quantified in the autoradiographic analysis represent the sum of $4 \mathrm{~h}$ of synthesis after the indicated time of recovery. Homogenization of gill tissue, preparation of samples for autoradiography, SDS-polyacrylamide electrophoresis, and fluorography all followed the protocol in Tomanek and Somero (1999).

Because heat-shock-inducing temperatures are experienced 
in the intertidal under both aquatic (tidepool) and aerial conditions, we determined how the heat-shock responses of $T$. funebralis and T. brunnea differed under these two conditions of exposure. We compared levels of hsp synthesis between snails exposed to $30^{\circ} \mathrm{C}$ in SW (time point 0 ) with snails exposed to $30^{\circ} \mathrm{C}$ air for $2.5 \mathrm{~h}$ on moist paper substrate at a single time point. Gill tissue of snails was dissected immediately after the exposure ( $0 \mathrm{~h}$ time point) and radiolabeled for $4 \mathrm{~h}$ under aeration. All other steps followed the procedures described in Tomanek and Somero (1999).

Image Analysis, Quantification of Expression of Heat-Shock Proteins, and Statistical Analyses

Film images were digitized with a scanner (Sharp JX-330) and analyzed with image analysis software (ImageMaster 1D, Version 2.01, Pharmacia). We express all hsp-band intensities relative to the respective band intensity of the $13^{\circ} \mathrm{C}$ control to account for potential differences in the overall level of protein synthesis between the two species (see Tomanek and Somero 1999). Levels of hsp synthesis, therefore, express the increase or decrease of synthesis relative to the control $\left(13^{\circ} \mathrm{C}\right)$ group.

Note that although hsp's are named according to molecular mass, we have not established homologies of these putative hsp's with those from other species. In addition, using onedimensional electrophoresis, we could not exclude the possibility that hsp bands that were assigned to a specific size class contain more than one hsp homologue.

Hsp band intensities among different recovery times within a species were compared to the $13^{\circ} \mathrm{C}$ control group by using a one-sided Dunnett test after a one-way ANOVA (SYSTAT Software, SYSTAT 6.0, SPSS). For the ANOVA, data were logtransformed and time of recovery was used as the independent variable and hsp-band intensity as the dependent variable. The first time at which the level of an hsp was significantly different $(P \leq 0.05)$ from the $13^{\circ} \mathrm{C}$ control level represents the time of onset of synthesis of that hsp. The first time at which the level of hsp synthesis returned to, and remained at, a level of hsp expression not different from the $13^{\circ} \mathrm{C}$ control is defined as the time of recovery (completion of the heat-shock response). For the comparison of hsp-band intensities after exposure to $30^{\circ} \mathrm{C}$ under aquatic or aerial conditions, we used a Student $t$ test to compare means.

\section{Results}

Effects of $30^{\circ} \mathrm{C}$ Exposure under Aquatic Conditions on Survival of Tegula funebralis and Tegula brunnea

A $2.5 \mathrm{~h}$ exposure (aquatic) to $30^{\circ} \mathrm{C}$ had significantly different effects on the mortality of Tegula brunnea and Tegula funebralis (Fig. 1). Tegula brunnea showed almost complete mortality over the 50-h postexposure period, whereas T. funebralis showed no mortality.

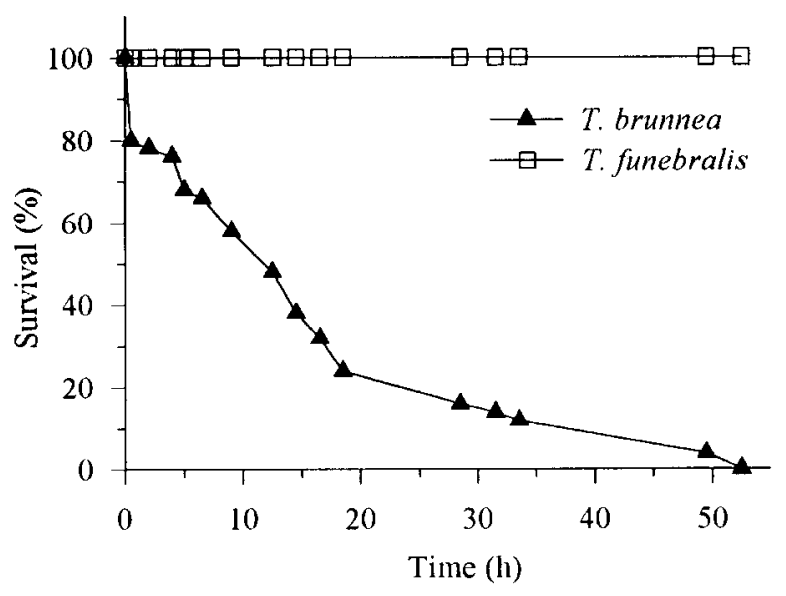

Figure 1. Time course of survival at $13^{\circ} \mathrm{C}$ of $13^{\circ} \mathrm{C}$-acclimated Tegula funebralis and Tegula brunnea, after immersion in $30^{\circ} \mathrm{C}$ seawater for $2.5 \mathrm{~h}$ ( $n=50$ for each species).

Time Course of Heat-Shock Protein Expression during Recovery from Heat Stress

The autoradiographs in Figure 2 show the patterns of protein synthesis during the $50-\mathrm{h}$ recovery period. As predicted, $T$. funebralis and T. brunnea differed significantly in the temporal patterning and intensity of the heat-shock response. The onset of hsp synthesis was consistently more rapid for T. funebralis. For all size classes of hsp's, induction in T. funebralis was noted at the earliest time point, and the heat-shock response was maximal after $1-3 \mathrm{~h}$ of recovery (Figs. 2, 3). The rate of decrease in the intensity of the response varied among hsp's (Fig. 3). For hsp70, synthesis decreased to control levels (a 2.5-h exposure at $13^{\circ} \mathrm{C}$, followed by $4 \mathrm{~h}$ of labeling) after $6 \mathrm{~h}$ of recovery. Synthesis of hsp38 was significantly higher than control levels only after $30 \mathrm{~min}$ postexposure. For hsp77 and hsp90, synthesis fell to control levels after $6 \mathrm{~h}$ and $14 \mathrm{~h}$, respectively. The stress response in $T$. funebralis, therefore, can be initiated and largely completed within the time period of immersion between two consecutive extreme midday low tides (Tomanek and Somero 1999).

In T. brunnea, induction of hsp's was initiated more slowly during recovery at $13^{\circ} \mathrm{C}$ than in $T$. funebralis, especially for hsp90 and hsp77, which required $14 \mathrm{~h}$ and $12 \mathrm{~h}$, respectively, to show significant increases in synthesis (Figs. 2, 3). Hsp70 and hsp38 were significantly induced by $2 \mathrm{~h}$ of recovery. The maximal intensity of hsp synthesis was uniformly higher in $T$. brunnea. For instance, whereas synthesis of hsp70 was enhanced approximately fivefold in T. funebralis, an approximately 14fold induction occurred in T. brunnea by $15 \mathrm{~h}$ of recovery. The delayed induction of synthesis, the prolonged period of synthesis, and the higher intensity of synthesis in T. brunnea are 


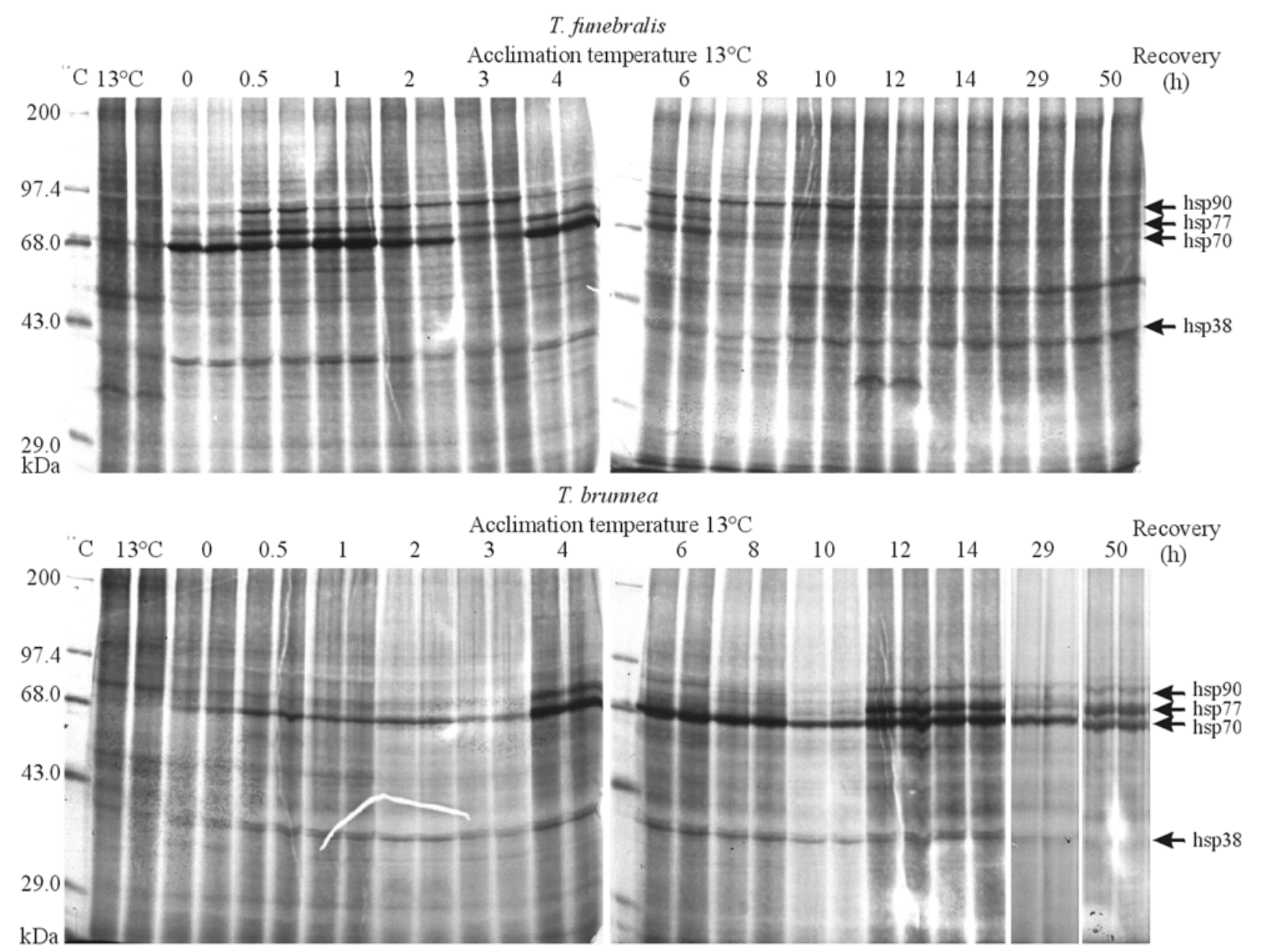

Figure 2. Autoradiographs showing the time course of incorporation of ${ }^{35} \mathrm{~S}$-methionine and ${ }^{35} \mathrm{~S}$-cysteine into proteins of gill tissue of Tegula funebralis and Tegula brunnea during $50 \mathrm{~h}$ of recovery at $13^{\circ} \mathrm{C}$, following a 2.5 -h immersion in $30^{\circ} \mathrm{C}$ seawater. Lanes represent de novo synthesis of proteins within $4 \mathrm{~h}$ after a certain time of recovery. For each time point, duplicates of a single snail's gill sample were loaded on a $10 \%$ SDS-polyacrylamide gel. ${ }^{14} \mathrm{C}$ molecular weight markers are shown in the far left lane of each autoradiograph. All lanes were loaded with 500,000 counts $\min ^{-1}$ and exposed for $8 \mathrm{~h}$ to preflashed $\mathrm{x}$-ray film.

all consistent with a higher level of stress from exposure to $30^{\circ} \mathrm{C}$, as compared with T. funebralis.

An additional interspecific difference is evident in comparisons of the patterns of synthesis shown in Figure 2. Gills of T. brunnea exhibited a stronger pattern of preferential synthesis of hsp's relative to other proteins, throughout recovery.

\section{Heat-Shock Responses under Aquatic and Aerial Conditions}

Thermal conditions that can induce heat shock may be present in small tidepools, as well as under aerial conditions during low tide. To determine how the heat-shock responses of $T$. funebralis and T. brunnea compare under aquatic and aerial conditions, $13^{\circ} \mathrm{C}$-acclimated specimens of both species were exposed to a $30^{\circ} \mathrm{C}$ heat shock for $2.5 \mathrm{~h}$ while immersed (see recovery experiment, $0 \mathrm{~h}$ time point) or exposed to humidified $30^{\circ} \mathrm{C}$ air (Fig. 4). As would be predicted by the different heatconducting properties of water and air, the rate of heating differed between treatments. Body temperatures of snails transferred from $13^{\circ} \mathrm{C} \mathrm{SW}$ to $30^{\circ} \mathrm{C} \mathrm{SW}$ increased, on average, by $4.50^{\circ} \mathrm{C} \mathrm{min}^{-1}$ (over the time period that was necessary to reach $30^{\circ} \mathrm{C}$ ); temperatures of snails transferred from $13^{\circ} \mathrm{C} \mathrm{SW}$ to humid air at $30^{\circ} \mathrm{C}$ increased by $0.42^{\circ} \mathrm{C} \mathrm{m^{-1 }}$. Thus, body temperatures of snails increased about 10 times faster in water than in air. As a consequence, the actual time snails spent at $30^{\circ} \mathrm{C}$ was shorter in air than under water, and aerial exposure thus should represent a lower level of thermal stress.

In the case of $T$. funebralis, we found no significant differ- 

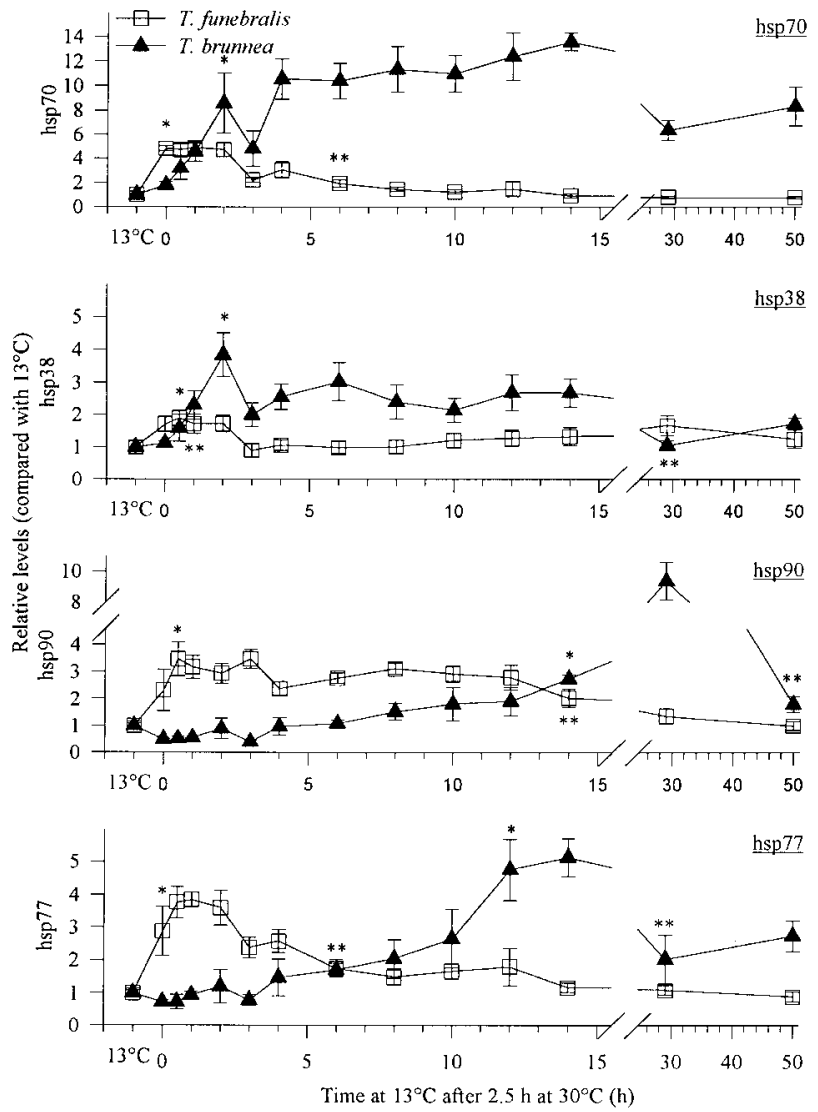

Figure 3. Time course of synthesis of proteins of size classes $70 \mathrm{kDa}$ (hsp70), $38 \mathrm{kDa}$ (hsp38), $90 \mathrm{kDa}$ (hsp90), and $77 \mathrm{kDa}$ (hsp77) at $13^{\circ} \mathrm{C}$ in $13^{\circ} \mathrm{C}$-acclimated Tegula funebralis and Tegula brunnea after a $2.5-\mathrm{h}$ immersion in $30^{\circ} \mathrm{C}$ seawater. Hsp levels are given relative to the $13^{\circ} \mathrm{C}$ control group and represent de novo synthesis of hsp's during $4 \mathrm{~h}$ of labeling after a certain time of recovery. An asterisk indicates the first time point at which hsp-band intensity is significantly $(P<0.05)$ different from the $13^{\circ} \mathrm{C}$ control group; two asterisks indicate the time point at which hsp synthesis returned to and remained at control levels. Data are means \pm 1 SEM ( $n=5$ for all data points except for T. brunnea: $13^{\circ} \mathrm{C}$ control group $[n=4], 1 \mathrm{~h}[n=4], 4 \mathrm{~h}[n=4, n=5$ for hsp77], $10 \mathrm{~h}$ [ $n=4$ for hsp70 and hsp77, $n=3$ for hsp90], $12 \mathrm{~h}$ [ $n=4$ only for hsp77], and $50 \mathrm{~h}$ [ $n=4$ for hsp38] time point).

ences in levels of hsp synthesis between aerial and aquatic heating for any hsp $(P<0.05)$ when we compared the $0 \mathrm{~h}$ time point of the recovery period, following exposure to $30^{\circ} \mathrm{C}$. In T. brunnea, however, aerial heating led to levels of hsp expression that were three to four times higher in case of hsp38, hsp77, and hsp90 and approximately six times higher for hsp70 $(P<0.05)$. Thus, although the total period at which body temperature remained at $30^{\circ} \mathrm{C}$ was shorter under aerial exposure, the slower rate of heating enabled T. brunnea to rapidly induce levels of hsp synthesis that not only exceeded those measured in conspecifics immersed at $30^{\circ} \mathrm{C}$ but also were substantially higher than those found in specimens of T. funebralis immersed at $30^{\circ} \mathrm{C}$ (Fig. 4 ).

\section{Discussion}

Timing and Magnitude of the Heat-Shock Responses of Tegula Congeners: Implications for Vertical Zonation

The subtidal to low-intertidal Tegula brunnea and the low- to mid-intertidal Tegula funebralis differed in the time of initiation, the duration, and the magnitude of the heat-shock response, following $2.5 \mathrm{~h}$ of immersion at $30^{\circ} \mathrm{C}$. Tegula funebralis, which frequently experiences $30^{\circ} \mathrm{C}$ in its mid-intertidal habitat (Tomanek and Somero 1999), activated and completed the heat-shock response faster and synthesized lower levels of hsp's than its lower-occurring congener. By being able to quickly activate its heat-shock response and complete synthesis of hsp's within $6 \mathrm{~h}$ (except for hsp90), T. funebralis may be able to repair protein damage incurred during one midday low tide before the occurrence of the next low tide and to accumulate within its cells adequate levels of hsp's to cope with the next bout of heat stress. In contrast, hsp synthesis in T. brunnea was activated more slowly and, in the case of hsp70, did not return to the prestress level of synthesis even after $50 \mathrm{~h}$ of recovery. Thus, T. brunnea seems less capable than its congener of repairing, during the subsequent period of reimmersion, the protein damage inflicted by the thermal conditions of a midday low tide period.

The higher magnitude of synthesis of hsp's eventually attained by T. brunnea relative to T. funebralis, following $2.5 \mathrm{~h}$ of immersion at $30^{\circ} \mathrm{C}$, suggests that it incurred greater thermal damage to its proteins than did its congener under these exposure conditions.

The different responses of T. brunnea under immersion and aerial exposure at $30^{\circ} \mathrm{C}$ show that the rate of heating may influence the timing and magnitude of synthesis of hsp's. The more rapid induction of hsp synthesis after aerial heat stress and the higher levels of synthesis attained in the $0 \mathrm{~h}$ recovery specimens suggest that a slower-occurring heat stress may allow an organism to mount a large-scale heat-shock response following exposure to a temperature that, were it to cause rapid heating, would cause a delayed onset and a more prolonged period of hsp synthesis. The observation that snails synthesized a higher amount of hsp's early in the recovery period after aerial heating, despite the fact that the actual time snails spent at $30^{\circ} \mathrm{C}$ was shorter in air than under water, is therefore an indication that this heat-shock treatment caused a lower level of heat stress than heating under immersion.

Studies of Drosophila have shown that the rate of heating plays an important role in the kinetics of the stress response (Lindquist 1980; DiDomenico et al. 1982b). Slower heating rates allow Drosophila cells to extend their temperature range of hsp synthesis; in contrast, rapid heating rates block tran- 

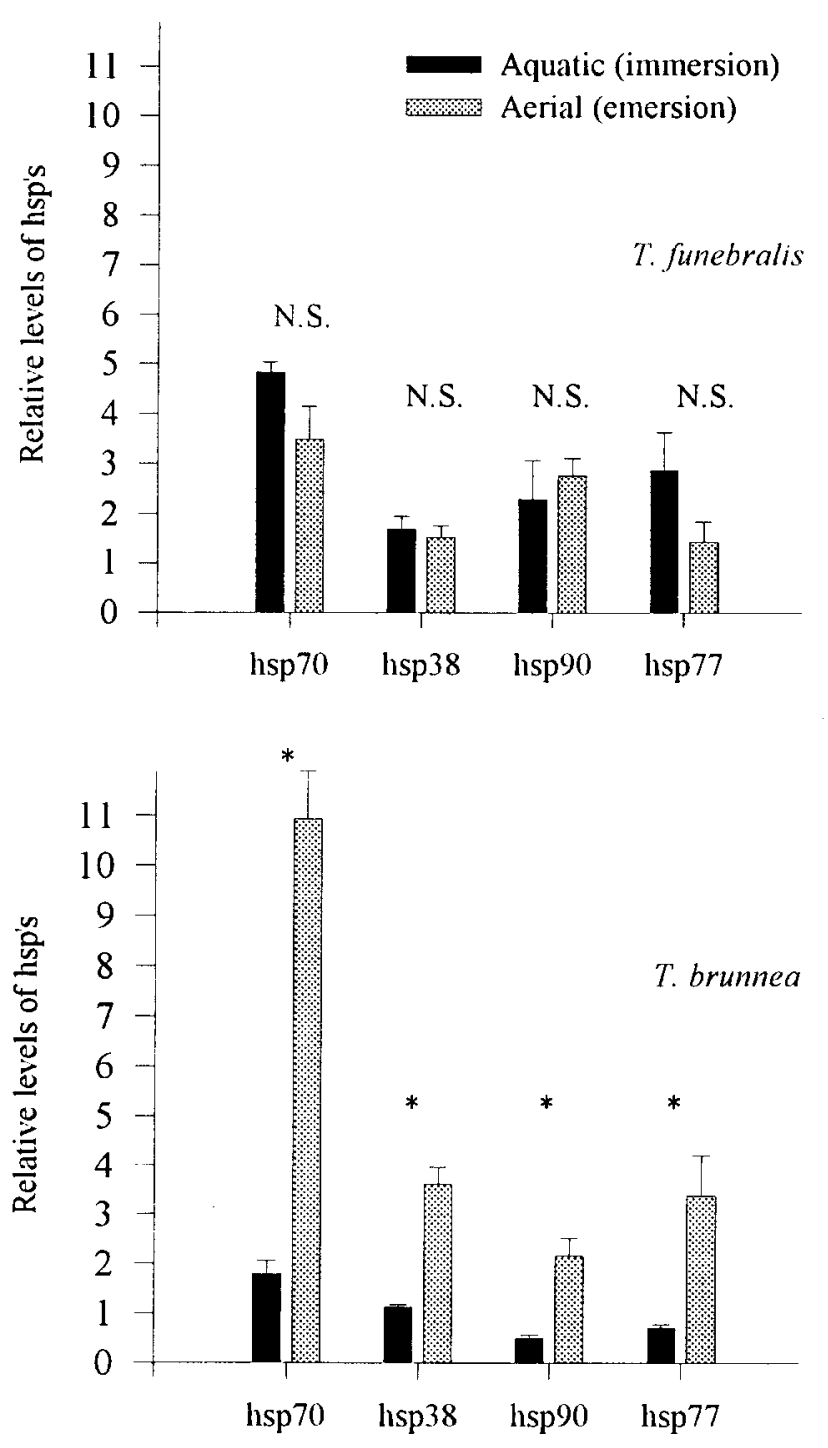

Figure 4. Levels of newly synthesized proteins of size classes $70 \mathrm{kDa}$ (hsp70), $38 \mathrm{kDa}$ (hsp38), $90 \mathrm{kDa}$ (hsp90), and $77 \mathrm{kDa}$ (hsp77) at $13^{\circ} \mathrm{C}$ in $13^{\circ} \mathrm{C}$-acclimated Tegula funebralis and Tegula brunnea after a 2.5 -h exposure to $30^{\circ} \mathrm{C}$, under aquatic and aerial conditions. Hsp levels are given relative to the $13^{\circ} \mathrm{C}$ control group and represent de novo synthesis of hsp's during $4 \mathrm{~h}$ of labeling with ${ }^{35} \mathrm{~S}$-methionine $/{ }^{35} \mathrm{~S}$-cysteine. Data are means \pm 1 SEM ( $n=5$ for all data points). NS = not significant; asterisk $=P<0.05$.

scription and thereby limit the temperature range of hsp synthesis. Thus, thermal effects on transcription may in part explain why T. brunnea was able to synthesize higher levels of hsp's under aerial conditions (Fig. 4) and why the induction of the heat-shock response was delayed in T. brunnea, following exposure to aquatic conditions (Figs. 2, 3).

The ability of a cell to mount an effective heat-shock response also may be influenced by the stability of its translational apparatus at high temperatures. Constitutive levels of hsp's may be important in this context because hsp70 is conjectured to bind to and stabilize its mRNA (DiDomenico et al. 1982a; Beck and De Maio 1994). Therefore, if constitutive levels of hsp's are relatively low in T. brunnea under typical field conditions of infrequent emersion and heat stress (Tomanek 1999), this species' translational capacity may be poorly protected from the effects of heat shock.

The relatively greater severity of the $30^{\circ} \mathrm{C}$ exposure under immersion to T. brunnea, relative to its congener, is also indicated by the inhibition of synthesis of most proteins other than hsp's over much of the recovery period, but especially at the $29 \mathrm{~h}$ and $50 \mathrm{~h}$ time points (Fig. 2). It is commonly observed that mRNAs of hsp's are preferentially translated following extreme heat stress (Lindquist 1980, 1981, 1993; Storti et al. 1980). The preferential translation of hsp's is likely to disrupt protein homeostasis, leading to an additional form of damage to the cell.

In conclusion, the multiple classes of perturbation to the cell that a heat stress imposes, including direct loss of protein function through thermal denaturation of existing proteins; the reduced synthesis of proteins other than hsp's, with concomitant effects on metabolism; and the energy costs entailed in the repairing and degrading of damaged proteins (Feder et al. 1992; Krebs and Loeschke 1994; Heckathorn et al. 1996) may contribute significantly to defining the limits of a species' thermal niche. These types of perturbations may be significantly higher for a lower-occurring, more heat-sensitive species like T. brunnea than for a more thermotolerant, higher-occurring congener like T. funebralis under conditions of exposure to heat stress found in the low- to mid-intertidal zone (Tomanek and Somero 1999). The distinct vertical distribution ranges of these two species, thus, may derive in part from the different intensities of heat stress the two species would experience during periods of emersion during low tides. Studies of congeneric porcelain crabs (genus Petrolisthes) with different vertical distribution ranges along the subtidal to intertidal gradient also illustrate the importance of differences in tolerance of physiological systems to high temperatures in establishing vertical zonation (Stillman and Somero 1996, 2000, in this issue).

\section{Experimental Design Influences the Observed Properties of the Heat-Shock Response}

Our studies of the heat-shock responses of congeners of Tegula illustrate that the magnitude and timing of the response are dependent on several factors: (1) genetically based interspecific differences, (2) the previous thermal history (acclimation and acclimatization state) of an individual, (3) the absolute temperature of exposure, (4) the rate with which this temperature is reached, (5) the duration of the exposure, and (6) the time(s) at which hsp synthesis is measured following thermal stress 
(Tomanek and Somero 1999). All of these factors must be considered in experimental design if biologically realistic descriptions of the heat-shock responses in situ of different species are to be obtained.

In a previous study (Tomanek and Somero 1999), we reported interspecific differences in the heat-shock responses of identically acclimated specimens of four Tegula congeners. However, levels of hsp synthesis were only compared at a single time point during recovery ( $15 \mathrm{~min})$. The time course of the heat-shock response shown in the present study revealed additional patterns of interspecific differences that could not be detected by comparing a single time point. Differences in the time of induction, the duration of elevated levels of synthesis, and the total quantity of hsp synthesis were revealed only by following the time course of the response for an extended period $(50 \mathrm{~h})$. Thus, to adequately evaluate the temporal patterning and intensity of the heat-shock response, the kinetics of the stress and recovery processes must be carefully considered in experimental design. When this is done, interspecific differences may be discerned that provide mechanistic explanations for the biogeographic patterning of species.

\section{Acknowledgments}

This study was supported by National Science Foundation grant IBN-9727721, the David and Lucile Packard Foundation, and the Dr. Earl H. Myers and Ethel M. Myers Grant for Oceanographic and Marine Biology (to L.T.).

\section{Literature Cited}

Abbott D.P. and E.C. Haderlie. 1980. Prosobranchia: marine snails. Pp. 230-307 in R.H. Morris, D.P. Abbott, and E.C. Haderlie, eds. Intertidal Invertebrates of California. Stanford University Press, Stanford, Calif.

Beck S. and A. De Maio. 1994. Stabilization of protein synthesis in thermotolerant cells during heat shock. J Biol Chem 269: 21803-21811.

DiDomenico B.J., G.E. Bugaisky, and S. Lindquist. 1982a. Heat shock and recovery are mediated by different translational mechanisms. Proc Natl Acad Sci USA 79:6181-6185.

- 1982b. The heat shock response is self-regulated at both the transcriptional and posttranscriptional levels. Cell 31:593-603.

Feder J.H., J.M. Rossi, J. Solomon, N. Solomon, and S. Lindquist. 1992. The consequences of expressing Hsp70 in Drosophila cells at normal temperatures. Genes Dev 6:14021413.
Feder M.E. and G.E. Hofmann. 1999. Heat shock proteins, molecular chaperones, and the stress response: evolutionary and ecological physiology. Annu Rev Physiol 61: 243-282.

Feige U., R.I. Morimoto, I. Yahara, and B.S. Polla. 1996. Stress Inducible Cellular Responses. Birkhäuser, Basel.

Heckathorn S.A., G.J. Poeller, J.S. Coleman, and R.L. Hallberg. 1996. Nitrogen availability alters patterns of accumulation of heat stress-induced proteins in plants. Oecologia 105: 413-418.

Hofmann G.E. and G.N. Somero. 1995. Evidence for protein damage at environmental temperatures: seasonal changes in levels of ubiquitin conjugates and hsp70 in the intertidal mussel Mytilus trossulus. J Exp Biol 198:1509-1518.

- 1996a. Interspecific variation in thermal denaturation of proteins in the congeneric mussels Mytilus trossulus and M. galloprovincialis: evidence from the heat-shock response and protein ubiquitination. Mar Biol 126:65-75.

- 1996b. Protein ubiquitination and stress protein synthesis in Mytilus trossulus occurs during recovery from tidal emersion. Mol Mar Biol Biotechnol 5:175-184.

Krebs R.A. and V. Loeschke. 1994. Costs and benefits of activation of the heat-shock response in Drosophila melanogaster. Funct Ecol 8:730-737.

Lindquist S. 1980. Varying patterns of protein synthesis in Drosophila during heat shock: implications for regulation. Dev Biol 77:463-479.

- 1981. Regulation of protein synthesis during heat shock. Nature 293:311-314.

. 1993. Autoregulation of the heat shock response. Pp. 279-320 in J. Ilan, ed. Translational Regulation of Gene Expression. Vol. 2. Plenum, New York.

Morimoto R.I. 1998. Regulation of the heat shock transcriptional response: cross talk between a family of heat shock factors, molecular chaperones, and negative regulators. Genes Dev 12:3788-3796.

Parsell D.A. and S. Lindquist. 1993. The function of heat-shock proteins in stress tolerance: degradation and reactivation of damaged proteins. Annu Rev Genet 27:437-496.

- 1994. Heat shock proteins and stress tolerance. Pp. 457-494 in R.I. Morimoto, A. Tissieres, and C. Georgopoulos, eds. The Biology of Heat Shock Proteins and Molecular Chaperones. Cold Spring Harbor Monograph Series. Cold Spring Harbor Laboratory, New York.

Riedman M.L., A.H. Hines, and J.S. Pearse. 1981. Spatial segregation of four species of turban snails (Gastropoda: Tegula) in central California. Veliger 24:97-102.

Roberts D.A., G.E. Hofmann, and G.N. Somero. 1997. Heatshock protein expression in Mytilus californianus: acclimatization (seasonal and tidal-height comparisons) and acclimation effects. Biol Bull 192:309-320.

Stillman, J.H. and G.N. Somero. 1996. Adaptation to temperature stress and aerial exposure in congeneric species of in- 
tertidal porcelain crabs (genus Petrolisthes): correlation of physiology, biochemistry and morphology with vertical distribution. J Exp Biol 199:1845-1855.

. 2000. A comparative analysis of the upper thermal tolerance limits of eastern Pacific porcelain crabs, genus $\mathrm{Pe}$ trolisthes: influences of latitude, vertical zonation, acclimation, and phylogeny. Physiol Biochem Zool 73:000-000.

Storti R.V., M.P. Scott, A. Rich, and M.L. Pardue. 1980. Translational control of protein synthesis in response to heat shock in D. melanogaster cells. Cell 22:825-834.

Tomanek L. 1999. The Heat Shock Response and Its Regulation in Congeneric Marine Snails (Genus Tegula) from Different
Thermal Habitats: Implications for Limits of Thermotolerance and Biogeographic Patterning. PhD diss. Oregon State University.

Tomanek L. and G.N. Somero. 1999. Evolutionary and acclimation-induced variation in the heat-shock responses of congeneric marine snails (genus Tegula) from different thermal habitats: implications for limits of thermotolerance and biogeography. J Exp Biol 202:2925-2936.

Watanabe J.M. 1984. The influence of recruitment, competition, and benthic predation on spatial distributions of three species of kelp forest gastropods (Trochidae: Tegula). Ecology 65:920-936. 